\title{
Malnutrition and parasitic helminth infections
}

\author{
L. S. STEPHENSON ${ }^{1 *}$, M. C. LATHAM ${ }^{1}$ and E. A. OTTESEN ${ }^{2}$ \\ ${ }^{1}$ Savage Hall, Program in International Nutrition, Division of Nutritional Sciences, Cornell University, Ithaca, \\ New York 14853 USA \\ ${ }^{2}$ Lymphatic Filariasis Elimination $(C P E / C E E / F I L)$, Department for Control, Prevention and Eradication, \\ World Health Organization, 1211 Geneva 27, Switzerland
}

\section{SU M M A R Y}

The Global Burden of Disease caused by the 3 major intestinal nematodes is an estimated $22 \cdot 1$ million disability-adjusted life-years (DALYs) lost for hookworm, 10.5 million for Ascaris lumbricoides, 6.4 million for Trichuris trichiura, and $39 \cdot 0$ million for the three infections combined (as compared with malaria at 35.7 million) (World Bank, 1993 ; Chan et al. 1994); these figures illustrate why some scarce health care resources must be used for their control. Strongyloides stercoralis is the fourth most important intestinal worm infection; its nutritional implications are discussed, and the fact that its geographic distribution needs further study is emphasized. Mechanisms underlying the malnutrition induced by intestinal helminths are described. Anorexia, which can decrease intake of all nutrients in tropical populations on marginal diets, is likely to be the most important in terms of magnitude and the probable major mechanism by which intestinal nematodes inhibit growth and development. We present a revised and expanded conceptual framework for how parasites cause/ aggravate malnutrition and retard development in endemic areas. Specific negative effects that a wide variety of parasites may have on gastrointestinal physiology are presented. The synergism between Trichuris and Campylobacter, intestinal inflammation and growth failure, and new studies showing that hookworm inhibits growth and promotes anaemia in preschool (as well as school-age) children are presented. We conclude by presenting rationales and evidence to justify ensuring the widest possible coverage for preschool-age children and girls and women of childbearing age in intestinal parasite control programmes, in order to prevent morbidity and mortality in general and specifically to help decrease the vicious intergenerational cycle of growth failure (of low-birth-weight/intrauterine growth retardation and stunting) that entraps infants, children and girls and women of reproductive age in developing areas.

Key words: Child malnutrition, malnutrition in pregnancy, hookworm, Ascaris lumbricoides, Trichuris trichiura, Strongyloides stercoralis.

GLOBAL BURDEN OF DISEASE CAUSED BY INTESTINAL NEMATODES

It is well recognized that intestinal worm infections are pervasive and, indeed, thrive in communities in need of better housing, sanitation, water supplies, health care, education and personal earnings (Crompton, 1999). Only through quantitative estimates, however, can a measure of the burden of disease and disability caused by these infections - burdens nearly always superimposed on malnourished bodies - be truly appreciated and recognized for the magnitude of resource consumption and wastage they cause in affected tropical communities.

\section{$D A L Y s$ and their calculation}

Initial attempts to estimate the disability-adjusted life years (DALYs) lost because of hookworm, Ascaris lumbricoides and Trichuris trichiura infections globally (World Bank, 1993) were subsequently refined (Chan et al. 1994; Bundy et al. 1997;

* Corresponding author: Tel: 1607255 6869. Fax: 1607 2556869 or 1607255 1033. E-mail: 1ss5@cornell.edu
Chan, 1997; de Silva et al. 1997 b) to account for the complexity of the morbidity associated with each of these infections (e.g. see Box 1). The most recent estimates of the burden associated with these and other selected diseases (expressed as DALYs) are recorded in Table 1 . Though perhaps not surprising to those with experience in areas where nearly all primary school children have hookworm and $40 \%$ are anaemic, where malaria is co-endemic, and where pregnant women with haemoglobin levels of $70 \mathrm{~g} / \mathrm{L}$ are not rare, the global DALY for hookworm (Table 1 ) is huge - an estimated $22 \cdot 1$ million life-years lost because of infection. The DALY for A. lumbricoides is 10.5 million, and that for $T$. trichiura is 6.4 million life-years lost due to the infection. The DALY for these intestinal nematodes combined is a whopping $39 \cdot 0$ million life-years, while that for malaria, which is inherently more overtly disabling, is similar, at 35.7 million life-years lost.

An estimated 1472 million persons harbour $A$. lumbricoides, 1298 millions are infected with hookworm, and about 1049 millions have T. trichiura (Crompton, 1999). Indeed, the global estimated prevalences of anaemia in hookworm infection and of cognitive impairment or deficit in hookworm, Ascaris and Trichuris infections (Table 2) indicate 
Box 1. Disease classification for Ascaris lumbricoides infection ${ }^{\mathrm{a}}$

(Used in re-calculation of disability-adjusted life years [DALYs])

Type A: Reversible growth faltering in children and/or reduced physical fitness in children and adults, which lasts for the duration of the infection. This deficit in health is recovered completely once the individual loses the infection (or the worm burden drops below a certain threshold; see Table below). All individuals with worm burdens over the lower threshold are considered to be at risk of type A morbidity.

Type B: Permanent growth retardation, which is a lifelong consequence of infection, occurring only in children. This deficit might be recovered, but only partially, even if the individual loses the infection completely. Type B morbidity was assumed to affect a very small proportion $(3 \%)$ of children ( $<15$ years) with worm burdens above the lower threshold.

Type C: Clinically overt, acute illness (such as intermittent abdominal pain or discomfort, nausea, anorexia or diarrhoea) of short duration and mild-moderate severity, sufficient for the infected individual to seek medical attention. All those with worm burdens over the higher threshold are at risk of type C morbidity.

Type D: Acute complications (including intestinal obstruction and its complications, biliary or pancreatic disease, appendicitis and peritonitis) of sufficient severity for the affected individual to be hospitalised. The probable number of cases of Ascaris-induced intestinal obstruction was calculated according to de Silva et al. (1997a) as $70 \%$ of all acute complications.

Type E: Mortality caused by acute complications (5\% case fatality rate assumed of those experiencing type D morbidity).

Age-dependent lower and higher worm-burden thresholds

\begin{tabular}{|c|c|c|}
\hline $\begin{array}{l}\text { Age group } \\
\text { (years) }\end{array}$ & $\begin{array}{l}\text { Lower threshold } \\
\text { worm burden }\end{array}$ & $\begin{array}{l}\text { Higher threshold } \\
\text { worm burden }\end{array}$ \\
\hline $0-5$ & 7 & 15 \\
\hline $5-10$ & 15 & 30 \\
\hline $10-15$ & 20 & 40 \\
\hline$>15$ & 20 & 40 \\
\hline
\end{tabular}

a Adapted from Chan, 1997 ; source
${ }^{\mathrm{b}}$ Number of worms per individual.

that for each parasite 10-50 million persons may be affected (Murray \& Lopez, 1996).

\section{Practical implications of quantifying disease burdens}

Such estimates of disease burden, even though impossible to make with complete accuracy, are extremely important because they can be used for decision-making to allocate scarce health-care resources and even to convince ministries of planning to opt for health as a primary tool for development. The World Development Report 1993 (World Bank, 1993 [the first WDR to contain DALYs]) stated clearly that mass treatment programmes for parasitic worms are again being recommended for truly largescale (global-level) funding because of (a) their costeffectiveness and (b) the burden of disease involved. This message is also being reinforced and updated in annual reports of other UN agencies concerned with health care (e.g. 'Progress against worms for pennies', in State of the World's Children 1998 [UNICEF, 1997]), since such wide-scale treatment programmes can be expected to have major impacts on human and community development and to produce quantifiable economic benefits.

\section{Malnutrition and Strongyloides infections}

Strongyloides stercoralis is the fourth most important intestinal nematode infection, but its impact is much less widely appreciated than those of Ascaris, Trichuris or hookworm infections. S. stercoralis is symptomatic in around $50 \%$ of cases, with diarrhoea, abdominal pain, nausea and vomiting being the common gastrointestinal symptoms (Milder et al. 1981; Nonaka et al. 1998). The known clinical 
Table 1. Global disability-adjusted life-years (DALYs) lost to hookworm, Ascaris lumbricoides, Trichuris trichiura and selected other infections*

\begin{tabular}{ll}
\hline \hline Cause of disability/mortality & $\begin{array}{l}\text { Life-years lost } \\
\text { (millions) }\end{array}$ \\
\hline Total intestinal helminths & $39 \cdot 0 *$ \\
Hookworms & $22 \cdot 1 *$ \\
Ascaris lumbricoides & $10 \cdot 5^{*}$ \\
Trichuris trichiura & $6 \cdot 4 *$ \\
Schistosomiasis & $4 \cdot 5$ \\
Measles & $34 \cdot 1$ \\
Vitamin A deficiency & $11 \cdot 8$ \\
Total maternal causes* & $29 \cdot 7$ \\
Malaria & $35 \cdot 7$ \\
Tuberculosis & $46 \cdot 5$ \\
Diabetes & $8 \cdot 0$ \\
\hline \hline
\end{tabular}

* Adapted from Chan (1997). DALY estimates are for the year 1990. Data for intestinal helminths from Bundy et al. (2000); all others from Murray \& Lopez (1994). Total Maternal Causes includes: haemorrhage, sepsis, eclampsia, hypertension, obstructed labour, and abortion.

features and potential or known nutritional outcomes are described in Table 3. The many nutritional consequences are of special concern because $S$. stercoralis can be of public health importance in children. In Bangladesh, for example, S. stercoralis was found to be most common in 7-10 year olds (prevalence $18 \%$ ), and it also infected $10 \%$ of 1-6 year olds (Hall et al. 1994). These preschool-age children are the most important at-risk age group for high nutritional morbidity and mortality rates.

Though prevalence and exact geographic distribution are still not well studied, S. stercoralis is known to be widely distributed throughout the tropics and subtropics. However, it is an infection still relatively neglected in field research and control programmes, compared to the other major intestinal nematodes of humans. This is despite repeated recommendations (Evans, Markus \& Steyn, 1990; Evans \& Stephenson, 1995) that surveys of intestinal nematodes in Africa record the prevalence and the larval and egg counts for both S. stercoralis and $S$. fuelleborni, a parasite of monkeys that also infects humans and is known to occur in South Africa, Namibia, and Papua New Guinea. Importantly, and unlike most other nematode infections of humans, since Strongyloides can undergo 'autoinfection', these infections have been reported to last more than 30 years in untreated humans. Also, infection with these parasites can be transmitted via breast milk.

\section{MECHANISMS UNDERLYING THE \\ MALNUTRITION INDUCED BY INTESTINAL HELMINTH INFECTIONS}

Just as the recent decade has significantly strengthened the link between malnutrition and infection (Stephenson et al. this volume), so too has it seen appreciable progress on defining the relationship between malnutrition and parasitic infections. Fig. 1 describes a conceptual framework for how infection with intestinal nematodes and other parasites may negatively influence an individual's nutritional status, and with it, his/her physical, cognitive, educational and overall societal development.

\section{Alimentary pathophysiology induced by infections}

To place in context how intestinal nematodes may affect nutritional status, the overview of alimentary physiology by Rosenberg \& Bowman (1984) and

Table 2. Global burdens: estimated prevalences of high intensity infections, anaemia in hookworm, and cognitive damage in hookworm, Ascaris lumbricoides and Trichuris trichiura infections: all ages and schoolage children

\begin{tabular}{|c|c|c|c|c|c|}
\hline \multirow[b]{2}{*}{ Infection } & \multicolumn{2}{|c|}{ High intensity infections } & \multirow{2}{*}{$\begin{array}{l}\text { Cognitive } \\
\text { impairment } \\
\text { Global total }\end{array}$} & \multirow[b]{2}{*}{$\begin{array}{l}\text { Global } \\
\text { total }\end{array}$} & \multirow[b]{2}{*}{$\begin{array}{l}5-14 \text { yr old } \\
{[\%] / \text { no. }}\end{array}$} \\
\hline & Global total & $\begin{array}{l}5-14 \text { yr old } \\
{[\%] / \text { no. }}\end{array}$ & & & \\
\hline & & & & \multicolumn{2}{|c|}{ Anaemia } \\
\hline Hookworm & 152492000 & $\begin{array}{c}{[68 \%]} \\
103695000\end{array}$ & 9568000 & $\begin{array}{c}{[72 \%]} \\
36014000\end{array}$ & 25930000 \\
\hline Ascaris lumbricoides & 61847000 & $\begin{array}{l}{[73 \%]} \\
45183000\end{array}$ & 52961000 & Cogr & $\begin{array}{l}\text { deficit } \\
{[95 \%]} \\
13856000\end{array}$ \\
\hline $\begin{array}{l}\text { Trichuris trichiura } \\
\text { Schistosomiasis (all spp.) }\end{array}$ & $\begin{array}{r}45421000 \\
208276000\end{array}$ & $\begin{array}{l}{[78 \%]} \\
35428000 \\
{[40 \%]} \\
83310000\end{array}$ & 39682000 & $\begin{array}{l}14585000 \\
18263000\end{array}$ & $\begin{array}{c}{[98 \%]} \\
17898000\end{array}$ \\
\hline
\end{tabular}

Adapted from Murray \& Lopez (1996). NB, Some estimates based on sparse data. Total population in areas endemic for geohelminthiases and schistosomiasis $=1655000000$ (Warren et al. 1993). 
Table 3. Clinical features of Strongyloides stercoralis infection and potential nutritional outcomes

\begin{tabular}{|c|c|c|}
\hline Stage and intensity of infection & Clinical features & Potential nutritional outcome \\
\hline Larval penetration of lungs by larvae & $\begin{array}{l}\text { Cutaneous manifestations due to larva migrans; } \\
\text { larva currens in the anal margin and buttocks }\end{array}$ & ? Decrease food intake \\
\hline Massive invasion of lungs by larvae & $\begin{array}{l}\text { Dyspnoea } \\
\text { Cough } \\
\text { Haemoptysis }\end{array}$ & ? Decrease food intake \\
\hline $\begin{array}{l}\text { Asymptomatic }[\sim 50 \% \text { of cases] } \\
\text { or light infections [majority of rest] }\end{array}$ & $\begin{array}{l}\text { Cough, malaise } \\
\text { Fever, headache, weakness }\end{array}$ & Decrease food intake \\
\hline $\begin{array}{l}\text { Chronic phase [which can be mild, } \\
\text { moderate or severe; moderate or severe } \\
\text { associated with heavier worm burden] }\end{array}$ & $\begin{array}{l}\text { Digestive manifestations: } \\
\text { Abdominal pain } \\
\text { Nausea } \\
\text { Diarrhoea } \\
\text { Vomiting } \\
\text { Weight loss } \\
\text { Increased white cell count } \\
\text { Acceleration of intestinal transit } \\
\text { Suggestions of or frank malabsorption } \\
\text { Duodenitis } \\
\text { Duodeno-jejunal hypotonia } \\
\text { Hypertonic ileum }\end{array}$ & $\begin{array}{l}\text { Decrease food intake } \\
\text { Decrease food intake } \\
\text { Increase nutrient loss } \\
\text { Increase nutrient loss }\end{array}$ \\
\hline $\begin{array}{l}\text { overe phase } \\
\text { overwing or disseminated) }\end{array}$ & $\begin{array}{l}\text { Diarrhoea with mucus and blood } \\
\text { Abdominal pain } \\
\text { Vomiting } \\
\text { Oedematous duodenitis } \\
\text { Hypotonia of the small intestine } \\
\text { Severe dehydration, electrolyte disturbance } \\
\text { Malnutrition and anasarca } \\
\text { Secondary hypoalbuminaemia } \\
\text { Paralytic ileus } \\
\text { Fibrosis due to bacterial invasion } \\
\text { Eosinophilia low to normal }\end{array}$ & $\begin{array}{l}\text { Increase nutrient loss } \\
\text { Decrease food intake } \\
\text { Increase nutrient loss } \\
\text { Decrease nutrient absorption and } \\
\text { increase nutrient loss } \\
\text { Increase nutrient and water losses } \\
\text { Increase protein loss, decrease intake } \\
\text { Decrease nutrient absorption and } \\
\text { increase nutrient loss }\end{array}$ \\
\hline
\end{tabular}

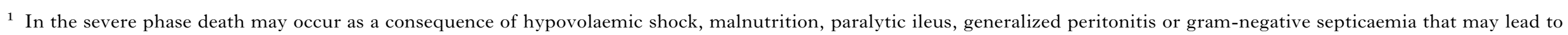
pneumonia or meningitis.

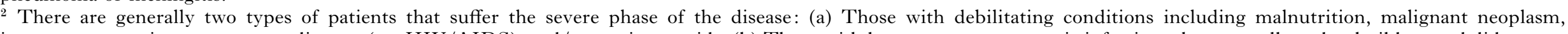

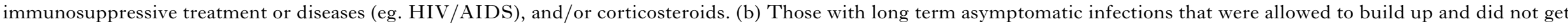
treated (Carvalho Filho, 1978).

Clinical features adapted from Carvalho Filho, 1978; Georgi, 1982; Milder et al. 1981; Nonaka et al. 1998. Table adapted from Stephenson \& Holland, 1987. 


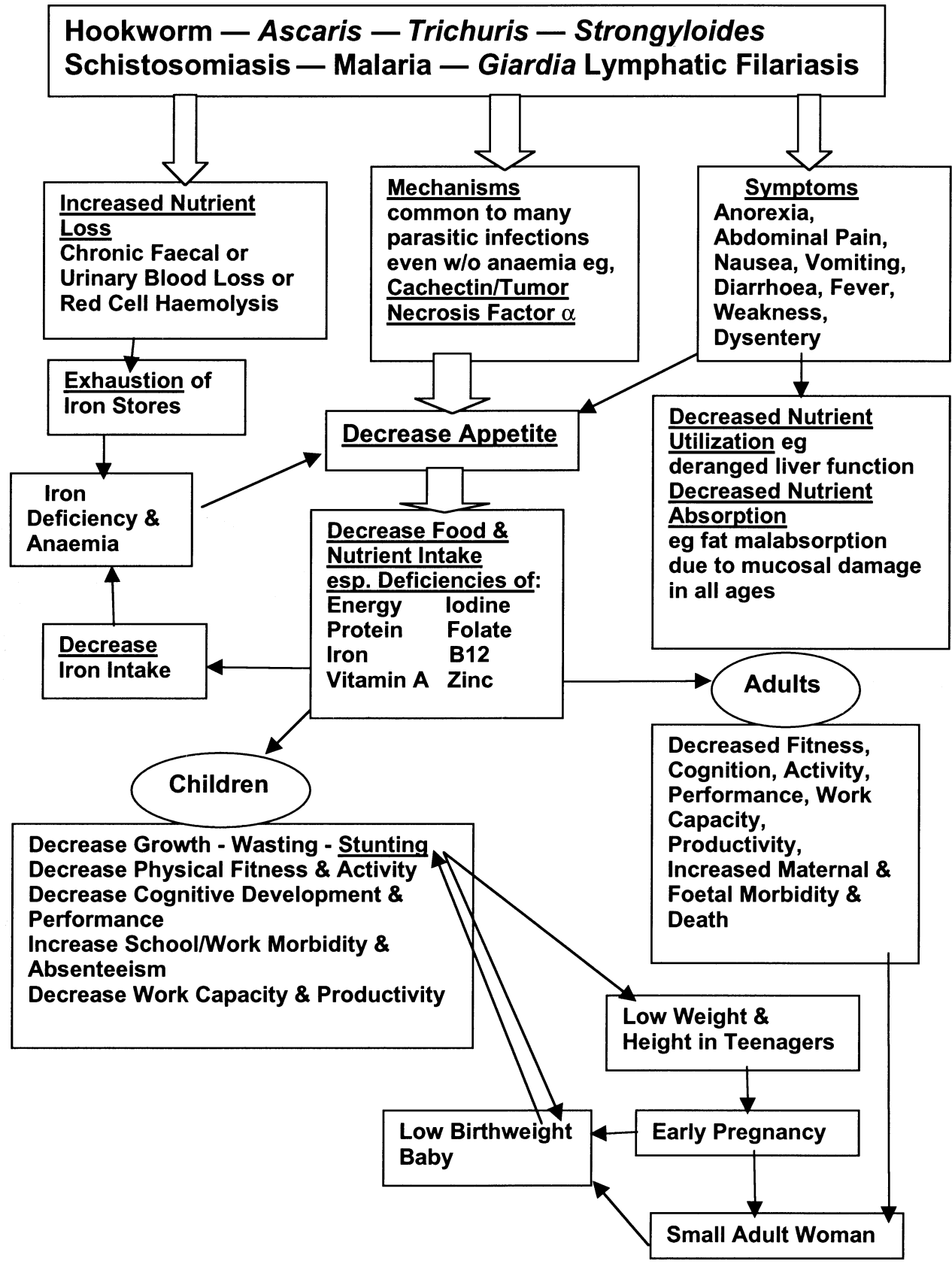

Fig. 1. Conceptual framework: How parasites cause/aggravate malnutrition and retard development. Adapted from Stephenson \& Holland, 1987 and ACC/SCN, 1992.

their compilation of the effects of a range of parasites on gastrointestinal physiology is particularly helpful (Table 4). Note that although most parasites listed are primarily lumen-dwelling, even some of those that are not can also negatively affect function of the GI tract, and most stages of digestion and absorption may be influenced. Indeed, most nutrients essential for humans may be affected by these infections (including sodium, potassium, and chloride, which are particularly related to vomiting and diarrhoea, Table 5). Without question, however, energy intake is the most important and most commonly compro- mised nutrient in children and other vulnerable groups in the tropics, including pregnant women. This decreased food intake is the consequence of a combination of appetite inhibition due to infections and of food withdrawal as misguided therapy for children and adults. When people consume less food energy, they also usually reduce their intake of essential micronutrients.

\section{Diminished food intake}

Anorexia. One of the most important mechanisms through which gut nematode infections can lower 
Table 4. Range of effects of parasitic infections on gastrointestinal physiology

\begin{tabular}{|c|c|c|}
\hline State & Effect & Parasite \\
\hline Food intake & Anorexia & Most helminths, protozoa \\
\hline Swallowing & Achalasia & Trypanosoma cruzi \\
\hline $\begin{array}{l}\text { Intestinal } \\
\text { propulsion/motility }\end{array}$ & $\begin{array}{l}\text { Increased/ } \\
\text { Decreased }\end{array}$ & $\begin{array}{l}\text { Trichinella spiralis }{ }^{\mathrm{a}} \\
\text { Eimeria } \text { spp. }\left({\text { coccidia })^{\mathrm{a}}}^{2}\right.\end{array}$ \\
\hline \multicolumn{3}{|l|}{ Luminal events } \\
\hline Stomach & $\begin{array}{l}\text { Achlorhydria/ } \\
\text { Hypochlorhydria }\end{array}$ & $\begin{array}{l}\text { Diphyllobothrium latum, } \\
\text { Giardia lamblia, Strongyloides } \\
\text { stercoralis, Schistosoma spp. }\end{array}$ \\
\hline Pancreas & $\begin{array}{l}\text { Hypergastrinaemia } \\
\text { Obstruction }\end{array}$ & $\begin{array}{l}\text { T. spiralis, Taenia taeniaeformis }{ }^{\mathrm{a}} \text {, } \\
\text { A. lumbricoides }\end{array}$ \\
\hline Liver & $\begin{array}{l}\text { Impaired digestion } \\
\text { Obstruction } \\
\text { Cellular damage }\end{array}$ & $\begin{array}{l}\text { G. lamblia; Eimeria spp. }{ }^{\mathrm{a}} \\
\text { A. lumbricoides, G. lamblia } \\
\text { Schistosoma } \text { spp. }\end{array}$ \\
\hline \multirow[t]{2}{*}{ Intestine } & Competition for nutrients & D. latum \\
\hline & $\begin{array}{l}\text { Bacterial overgrowth with } \\
\text { bile acid deconjugation }\end{array}$ & G. lamblia \\
\hline \multirow[t]{2}{*}{ Cellular events } & $\begin{array}{l}\text { Mucosal damage, } \\
\text { with endogenous losses }\end{array}$ & $\begin{array}{l}\text { Hookworm spp., } \\
\text { Entamoeba histolytica, } \\
\text { Capillaria philippinensis, S. stercoralis, } \\
\text { Trichuris trichiura }\end{array}$ \\
\hline & $\begin{array}{l}\text { Local irritation/damage } \\
\text { with malabsorption }\end{array}$ & $\begin{array}{l}\text { A. lumbricoides, G. lamblia, } C . \\
\text { phillippinensis, Isospora belli }\end{array}$ \\
\hline \multirow[t]{2}{*}{ Circulatory events } & $\begin{array}{l}\text { Obstruction of mesenteric } \\
\text { vessels }\end{array}$ & Schistosoma spp.; Plasmodium knowlesi ${ }^{\mathrm{a}}$ \\
\hline & Obstruction of lymphatics & $\begin{array}{l}\text { *Wuchereria bancrofti, } \\
\text { *Brugia malayi }\end{array}$ \\
\hline
\end{tabular}

a Animal data only. * Added for this volume. Adapted from Rosenberg \& Bowman, 1984.

Table 5. Nutrients adversely affected by intestinal pathogens

\begin{tabular}{ll}
\hline \hline $\begin{array}{l}\text { Carbohydrate } \\
\text { Monosaccharides } \\
\text { Disaccharides }\end{array}$ & $\begin{array}{c}\text { Mineral elements } \\
\text { Sodium } \\
\text { Potassium }\end{array}$ \\
Nitrogen/protein/amino acids & Chloride \\
Lipids & $\begin{array}{l}\text { Iron } \\
\text { Zinc }\end{array}$ \\
*Energy intakes & Magnesium \\
& Selenium \\
Vitamins & \\
Vitamin A & \\
Vitamin $\mathrm{B}_{12}$ & \\
Vitamin D & \\
Vitamin E & \\
Ascorbic acid & \\
Folic acid & \\
Pyridoxine & \\
Ascorbic acid & \\
\hline \hline
\end{tabular}

* Added for this volume. Adapted from Solomons, 1993

nutritional status is anorexia. That parasitic infections can and often do cause decreased food intake was elegantly presented by Crompton (1984) in a review of 23 studies in 6 species of animal hosts (rats, mice, pigs, sheep, domestic fowl) infected separately with 12 different species of helminth and protozoan parasites (Table 6). For 10 of 12 parasites, food intake was reduced for some period of time in infected vs. uninfected animals, and body weight gain was also reduced in infected animals.

This anorexia and diminished food intake associated with parasitic infections can be extremely important in affecting child growth, as our placebocontrolled field studies have demonstrated (Latham et al. 1990; Stephenson, 1993; Stephenson et al. 1993 b; Lawless et al. 1994; Hadju et al. 1996, 1998). In these, Kenyan and Indonesian primary school children were treated for infections with either Schistosoma haematobium (Kenya only, with metrifonate or praziquantel) or intestinal nematodes (hookworm, T. trichiura, and A. lumbricoides; with albendazole or pyrantel pamoate) or were treated for iron-deficiency anaemia (with ferrous sulphate), without treatment for worms. All showed significantly improved appetite 3 weeks to 4 months after treatment when children were offered all they could consume of a common local porridge at mid-day. Treated children not only consumed more food by objective measurement; they also reported sub- 
Table 6. Host-parasite relationships in which host food intake has been studied and usually reduced during the course of experimental infections

\begin{tabular}{|c|c|c|c|c|c|c|c|}
\hline Host & Parasite & Route of infection & $\begin{array}{l}\text { Location of parasites } \\
\text { in host }^{\mathrm{a}}\end{array}$ & $\begin{array}{l}\text { Duration of } \\
\text { infection } \\
\text { (weeks) }\end{array}$ & Diet & $\begin{array}{l}\text { Food intake }{ }^{\mathrm{b}} \\
\text { (infected } \\
\text { vs. uninfected) }\end{array}$ & $\begin{array}{l}\text { Fresh body wt } \\
\text { (infected vs. } \\
\text { uninfected) }\end{array}$ \\
\hline Pig & Ascaris suum & $\begin{array}{l}\text { Ingestion of } \\
\text { embryonated eggs }\end{array}$ & $\begin{array}{l}\text { Lumen of anterior half } \\
\text { of small intestine }\end{array}$ & $\sim 11$ & $\begin{array}{l}\text { Experimental, } \sim 8 \% \\
(\mathrm{w} / \mathrm{w}) \text { protein }\end{array}$ & Reduced & Reduced \\
\hline Pig & Trichuris suis & $\begin{array}{l}\text { Ingestion of } \\
\text { embryonated eggs }\end{array}$ & $\begin{array}{l}\text { Mucosa \& paramucosal } \\
\text { lumen in large intestine }\end{array}$ & 11 & Complete & Reduced & Reduced \\
\hline Laboratory rat & $\begin{array}{l}\text { Nippostrongylus } \\
\text { brasiliensis }\end{array}$ & $\begin{array}{l}\text { Inoculation s.c. of } \\
\text { larvae }\end{array}$ & $\begin{array}{l}\text { Paramucosal lumen of } \\
\text { anterior part of small } \\
\text { intestine }\end{array}$ & $\sim 11$ & $\begin{array}{l}\text { Experimental } 1,2 \text {, and } \\
20 \% \text { protein }(\mathrm{w} / \mathrm{w})\end{array}$ & Reduced & Reduced \\
\hline Laboratory rat & Trichinella spiralis & $\begin{array}{l}\text { Oral intubation of } \\
\text { larvae }\end{array}$ & $\begin{array}{l}\text { Paramucosal lumen of } \\
\text { anterior part of small } \\
\text { intestine }\end{array}$ & 1 & Experimental & $\begin{array}{l}\text { Oral } \text { (natural }^{\mathrm{f}} \\
\text { Intraduodenal } \\
\text { i.v. }\end{array}$ & $\begin{array}{l}\text { Reduced } \\
\text { Similar } \\
\text { Similar }\end{array}$ \\
\hline Sheep & $\begin{array}{l}\text { Trichostrongylus } \\
\text { colubriformis }\end{array}$ & $\begin{array}{l}\text { Ingestion of } \\
\text { larvae }\end{array}$ & $\begin{array}{l}\text { Paramucosal lumen of } \\
\text { anterior part of small } \\
\text { intestine }\end{array}$ & $14-24$ & $\begin{array}{l}\text { Complete ruminant } \\
\text { diet }\end{array}$ & Reduced & Reduced \\
\hline Laboratory mouse & Schistosoma mansoni & $\begin{array}{l}\text { Skin penetration } \\
\text { by cercariae }\end{array}$ & $\begin{array}{l}\text { Portal and mesenteric } \\
\text { blood vessels }\end{array}$ & 7 & Complete & Reduced after 6 wk p.i. & Reduced \\
\hline Domestic fowl & $\begin{array}{l}\text { Eimeria spp., } \\
\text { E. necatrix }\end{array}$ & $\begin{array}{l}\text { Ingestion of } \\
\text { sporulated oocysts }\end{array}$ & Inside enterocytes & $\sim 2$ & $\begin{array}{l}\text { Standard poultry } \\
\text { rations, complete }\end{array}$ & 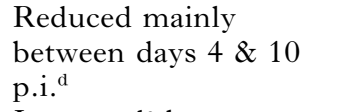 & Reduced \\
\hline Laboratory rat & Trypanosoma lewisi & $\begin{array}{l}\text { Inoculation of } \\
\text { trypanosome } \\
\text { homogenates }\end{array}$ & $\begin{array}{l}\text { Extracellular in blood, } \\
\text { lymph and tissues }\end{array}$ & Several & Complete & $\begin{array}{l}\text { Increased }^{\mathrm{e}} \text { between } \\
\text { days } 25-35 \text { p.i. }\end{array}$ & Increased $^{\mathrm{e}}$ \\
\hline Sheep & Fasciola hepatica & $\begin{array}{l}\text { Ingestion of } \\
\text { metacercariae }\end{array}$ & $\begin{array}{l}\text { Liver tissue and biliary } \\
\text { system }\end{array}$ & 40 & $\begin{array}{l}\text { Complete ruminant } \\
\text { diet }\end{array}$ & $\begin{array}{l}\text { Reduced from } 15 \text { wk } \\
\text { p.i. }\end{array}$ & Reduced \\
\hline Sheep & $\begin{array}{l}\text { Paramphistomum } \\
\text { microbothrium }\end{array}$ & $\begin{array}{l}\text { Ingestion of } \\
\text { metacercariae }\end{array}$ & Rumen & 36 & Lucerne hay & $\begin{array}{l}\text { Reduced from 6th day } \\
\text { p.i. }\end{array}$ & Reduced \\
\hline Cotton rat & $\begin{array}{l}\text { Litomosoides } \\
\text { carinii }\end{array}$ & $\begin{array}{l}\text { Introduction of } \\
\text { larvae via bite of } \\
\text { rat mites }\end{array}$ & Pleural cavity & 8 & $\begin{array}{l}\text { Experimental protein } \\
\text { varied } 2 \cdot 5-15 \%(\mathrm{w} / \mathrm{w})\end{array}$ & $\begin{array}{l}\text { Increased } \mathrm{ns} \\
(2.5 \text { and } 5 \% \text { protein })\end{array}$ & Similar \\
\hline Sheep & $\begin{array}{l}\text { Ostertagia } \\
\text { circumcincta }\end{array}$ & Ingestion of larvae & Mucosa of abomasum & 14 & $\begin{array}{l}\text { Complete ruminant } \\
\text { diet }\end{array}$ & Reduced & Reduced \\
\hline
\end{tabular}

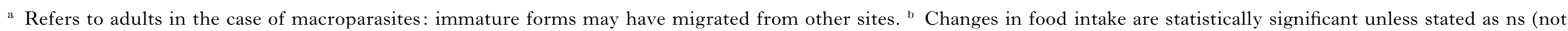

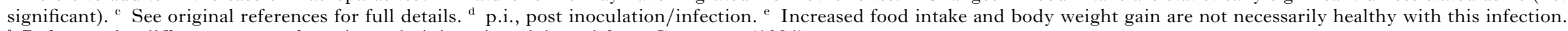

${ }^{\mathrm{f}}$ Refers to the different routes of nutrient administration. Adapted from Crompton (1984). 
jectively that their appetite had improved when they were asked to rate their appetite on a 5-point scale. These children gained more weight and significantly improved in other anthropometric measures as well, compared to placebo groups; and their physical fitness, measured by the Harvard Step Test, and spontaneous physical activity also increased significantly (Latham et al. 1990; Stephenson et al. 1993 b; Lawless et al. 1994; Adams et al. 1994; Hadju et al. 1996, 1998; see also O'Lorcain and Holland, this volume). Importantly, with respect to the potential benefits of treating worm infections on societal development, these children not only ate more and grew faster; they also were more active, and this in turn may positively influence intellectual development.

Consumption vs. hunger: cultural and therapeutic practices. In animals, our only measure of hunger is the level of feed consumed. In humans the situation is obviously more complex since cultural practices affect what children are offered to eat, and psychological factors affect how much people eat, regardless of appetite (defined here as the desire to eat or physical sensations of hunger). As Scrimshaw \& SanGiovanni (1997) point out, withdrawal of food from individuals with fever, diarrhoea, or other signs of infection is an almost universal practice that exacerbates the effect of anorexia. In most field studies, no attempt has been made to separate the effects of anorexia from those of deliberate withdrawal of food for cultural reasons, but the combined effects can be devastating. In Matlab, Bangladesh, food intakes as judged from dietary energy were $>40 \%$ reduced in children aged $<5$ years during the acute stage of diarrhoea compared with after recovery (Molla et al. 1983). In Peru, energy intakes decreased between $10 \%$ and $86 \%$ in breast-fed children with diarrhoea (Bentley et al. 1991). Mothers cannot help but think that if there is too much coming out of a child too fast, it must be therapeutic to put less in, and this likely applies regardless of the primary cause of the diarrhoea, be it parasitic, viral or bacterial.

\section{Intestinal co-infections}

While many different intestinal pathogens cause nutritional disturbances in humans, a recent intriguing observation has described augmented pathology in response to a specific co-infection. It was found that necrotic proliferative colitis (due to Campylobacter jejuni) in weanling pigs occurred only in animals previously innoculated with Trichuris suis at 8 weeks of age, but not in animals without $T$. suis infection. The mechanism was hypothesized to be a whipworm-induced suppression of mucosal immunity to the resident bacteria (Mansfield \& Urban, 1996). Regardless of the precise mechanism, this work may be of major relevance for children in the tropics, as it establishes a firm basis for the likely importance of synergistic interactions between helminth parasites and protozoal/bacterial/viral infections in enhancing the pathology associated with the gut nematodes, especially Trichuris trichiura, which resides in and damages the bacteria-rich caecum and colon.

Precise studies on the magnitude, and even just the effect, of such interactions are extremely difficult, expensive, labour-intensive, and both technically and sometimes ethically complex to conduct in infected children in tropical settings. The advantage of studying such pathogenesis in an animal model is obvious, and the use of $T$. suis in weanling pigs provides an especially good model for infection in children. (See discussion of animal models by Boes \& Helwigh, this volume.)

\section{Intestinal inflammation and growth failure}

All forms of chronic intestinal inflammation lead to growth failure, whether by secondary effects on nutrient balance or by more direct effects on metabolism (Cooper, 1991). Children with intense infections of $T$. trichiura have the symptoms and signs associated with chronic colitis of any cause; some suffer severe suppressions of growth in height, with corresponding spurts in height after treatment, at catch-up height velocities similar to those in children with coeliac disease placed on a gluten-free diet, or in pituitary dwarfs given growth hormone (Cooper et al. 1990; Cooper, 1991). Again, the T. suis model in weanling pigs with its intestinal inflammatory pathology could be highly relevant to understanding $T$. trichiura in children.

Intestinal inflammation is also believed to be an important mechanism contributing to poor growth in hookworm-infected children. Our earlier report of small but significant improvements in growth rates after treatment of Kenyan primary school children with light-moderate loads of hookworm (Stephenson et al. 1989) drew renewed attention to older observations of clinicians that growth stunting and delayed development are commonly observed in children with hookworm infection.

REVERSING MALNUTRITION AND ITS

CONSEQUENCES BY TREATING PARASITE

INFECTIONS

Focus - school-age children

An enormous proportion of the benefits from treating and preventing intestinal nematode infections derives from the childhood population (Table $7)$; there are an estimated 280 million hookworminfected children ( $<15$ years old) in the world, 478 millions with $A$. lumbricoides, and 347 millions with $T$. trichiura. There are 41 million hookworm- 
Table 7. Global estimates of Hookworm, Ascaris lumbricoides and Trichuris trichiura infections in pre-school age and school-age children by region*

\begin{tabular}{|c|c|c|c|c|c|c|c|c|c|}
\hline Helminth & & & $\begin{array}{l}\text { Sub- } \\
\text { Saharan } \\
\text { Africa }\end{array}$ & India & China & $\begin{array}{l}\text { Other } \\
\text { Asia \& } \\
\text { Islands }\end{array}$ & $\begin{array}{l}\text { Latin } \\
\text { America } \\
\text { \& Carib. }\end{array}$ & $\begin{array}{l}\text { Middle } \\
\text { Eastern } \\
\text { crescent }\end{array}$ & $\begin{array}{l}\text { Total } \\
\text { (millions/\%) }\end{array}$ \\
\hline Hookworm & $\begin{array}{l}\begin{array}{l}\text { Cases } \\
\text { (millions) }\end{array} \\
\text { Prevalence, } \\
\%\end{array}$ & $\begin{array}{l}\text { Preschool } \\
\text { School } \\
\text { Preschool } \\
\text { School }\end{array}$ & $\begin{array}{c}7 \\
34 \\
7 \% \\
24 \%\end{array}$ & $\begin{array}{l}10 \\
59 \\
9 \% \\
30 \%\end{array}$ & $\begin{array}{l}9 \\
49 \\
35 \% \\
42 \%\end{array}$ & $\begin{array}{r}8 \\
51 \\
9 \% \\
31 \% \\
\quad \text { To }\end{array}$ & $\begin{array}{l}4 \\
25 \\
7 \% \\
24 \% \\
\text { Idren with }\end{array}$ & $\begin{array}{c}4 \\
20 \\
5 \% \\
16 \% \\
\text { orm }\end{array}$ & $\begin{array}{c}41 \\
239 \\
7 \% \\
26 \% \\
280\end{array}$ \\
\hline Ascaris lumbricoides & $\begin{array}{l}\begin{array}{l}\text { Cases } \\
\text { (millions) }\end{array} \\
\text { Prevalence, } \\
\%\end{array}$ & $\begin{array}{l}\text { Preschool } \\
\text { School } \\
\text { Preschool } \\
\text { School }\end{array}$ & $\begin{array}{l}18 \\
33 \\
20 \% \\
23 \%\end{array}$ & $\begin{array}{l}25 \\
50 \\
21 \% \\
25 \%\end{array}$ & $\begin{array}{l}41 \\
79 \\
35 \% \\
42 \%\end{array}$ & $\begin{array}{l}39 \\
86 \\
46 \% \\
52 \% \\
\quad \text { To }\end{array}$ & $\begin{array}{l}21 \\
46 \\
37 \% \\
44 \% \\
\text { dren with }\end{array}$ & $\begin{array}{l}14 \\
27 \\
18 \% \\
22 \%\end{array}$ & $\begin{array}{l}158 \\
320 \\
29 \% \\
35 \% \\
478\end{array}$ \\
\hline Trichuris trichiura & $\begin{array}{l}\text { Cases } \\
\text { (millions) } \\
\text { Prevalence, } \\
\%\end{array}$ & $\begin{array}{l}\text { Preschool } \\
\text { School } \\
\text { Preschool } \\
\text { School }\end{array}$ & $\begin{array}{l}15 \\
27 \\
16 \% \\
20 \%\end{array}$ & $\begin{array}{l}18 \\
36 \\
15 \% \\
18 \%\end{array}$ & $\begin{array}{l}22 \\
42 \\
19 \% \\
23 \%\end{array}$ & $\begin{array}{l}32 \\
70 \\
37 \% \\
43 \% \\
\end{array}$ & $\begin{array}{l}18 \\
39 \\
32 \% \\
38 \% \\
\text { Idren with }\end{array}$ & $\begin{array}{c}9 \\
118 \\
12 \% \\
14 \% \\
\text { tris }\end{array}$ & $\begin{array}{l}114 \\
233 \\
21 \% \\
25 \% \\
347\end{array}$ \\
\hline
\end{tabular}

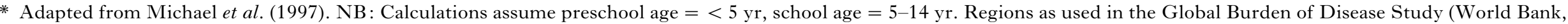
1993). 
infected children $<15$ years in sub-Saharan Africa alone. Hookworm burdens are heavier and prevalences tend to be higher in older children and adults, while Ascaris is much less common in adults. The benefits of treating school-age children for intestinal parasites have been documented repeatedly and convincingly (Stephenson et al. 1989; Bundy et al. 1999).

\section{Focus - preschool-age children}

Increasingly it is being recognized that treating preschool-age children (defined for the Global Burden of Disease study as $<5$ years) is particularly important, though often more difficult, for at least 2 reasons. First, preschoolers have many-fold higher case-fatality rates for many infections; second, keeping them relatively healthy as preschoolers definitely gives them a competitive edge in survival as school-age children and adults. Indeed, recent findings from a study of child growth in Northeastern Brazil suggest that preschoolers receiving a single treatment with albendazole may benefit nutritionally for years after treatment. The study followed children from $0-2$ years of age for 4 to 7 years and, importantly, helminthic infections during the first 2 years of life were associated with impaired growth (reduced height-for-age $Z$ scores) even at 6-9 years of age (Guerrant et al. 1999; Moore et al. 1999). Two other major findings were (a) that early childhood diarrhoea (from 0-2 years old) correlated with reduced physical fitness in the Harvard Step Test at 6-9 years of age, even after controlling for 6 different types of confounding variables, and (b) that early childhood cryptosporidial infection is also associated with reduced physical fitness at 6-9 years of age, even when controlling for current nutritional status. Thus, while many have assumed that children under 1 year or even 2 years usually has such light helminth infections, if any, that they were less worth examining and treating than 3-5 year olds - these results strongly imply the opposite. Further, since less physically fit children and adults are less productive at work requiring hard physical labour, as is often demanded of lower income people, rural or urban, these findings, if confirmed, could have a major impact on the re-calculation of disabilityadjusted life-years for these infections.

Additional support for the importance of helminth infections in preschool-age children comes from two recent studies in Kenya. These studies show clearly that hookworm infection in preschoolers can cause or aggravate anaemia, and that treatment, even of individuals with relatively low egg counts, can yield significant growth improvements. Hookworm has often been considered relatively unimportant in preschoolers and has not been frequently studied in detail, because prevalences and egg counts are lower than in older children who have had much more time to acquire significant worm loads. Brooker et al. (1999) found that $28 \%$ of 460 preschool children aged 6 to 60 months in Kilifi, Kenya had hookworm infection, that $76 \%$ were anaemic (haemoglobin $<110 \mathrm{~g} / \mathrm{L}$ ), and that anaemia was significantly more severe in children with hookworm infections $>200$ eggs per gram of faeces [epg]. For this and other reasons a cut-off of 200 epg appeared appropriate to define 'heavy' hookworm infections for this age range, even though an egg count ten-fold greater (2000 epg) is often used as the cutoff between "light" and "moderate" hookworm infections in older children and adults.

A second recent Kenyan study (Manjrekar, 1999) in Bungoma reported that treatment of sick, worminfected 2-4 year old children with a single dose of mebendazole yielded statistically significant gains in weight and height at 6 month follow-up. This finding is notable because worm infections seemed relatively unimportant in the overall group of children studied : only $12 \%$ of children were infected with any helminth, only $6 \%$ harboured hookworm, $6 \%$ had $A$. lumbricoides, and $1 \%$ had $T$. trichiura. These results re-emphasize the importance of anthelminthic treatment for infected preschoolers as well as for school-age children, even when the sick preschoolers exhibit low prevalences and egg counts.

Focus-girls and women of childbearing age : hookworm infection and its consequences

The burden of disease imposed on hookworminfected girls and women of childbearing age, especially when pregnant, may very well define the single most important contribution of intestinal nematode infections to the calculation of their global disease burden. Pregnancy requires extra nutrients, especially iron, and produces a 'physiological anaemia' due to haemodilution (Steer, 2000). The anaemia results in both decreased appetite, and lowered aerobic and physical work capacity, even without the added weight gain to transport - and this is in girls and women who, in the tropics, must often carry their youngest child and the household water supply long distances and also manage to till their fields daily without mechanized equipment. The total amount of work a woman can do in a day definitely decreases when she is anaemic, whatever the cause, and pregnancy plus hookworms produce a double burden for women in agriculture. Indeed, it is ironic that women in some rural farming communities may even acquire hookworms in the process of growing the family's food and thus increase their degree of anaemia in pregnancy, as for example, in Vietnam, where insufficiently composted human faeces may be used as fertilizer on vegetable crops (Humphries et al. 1997). 


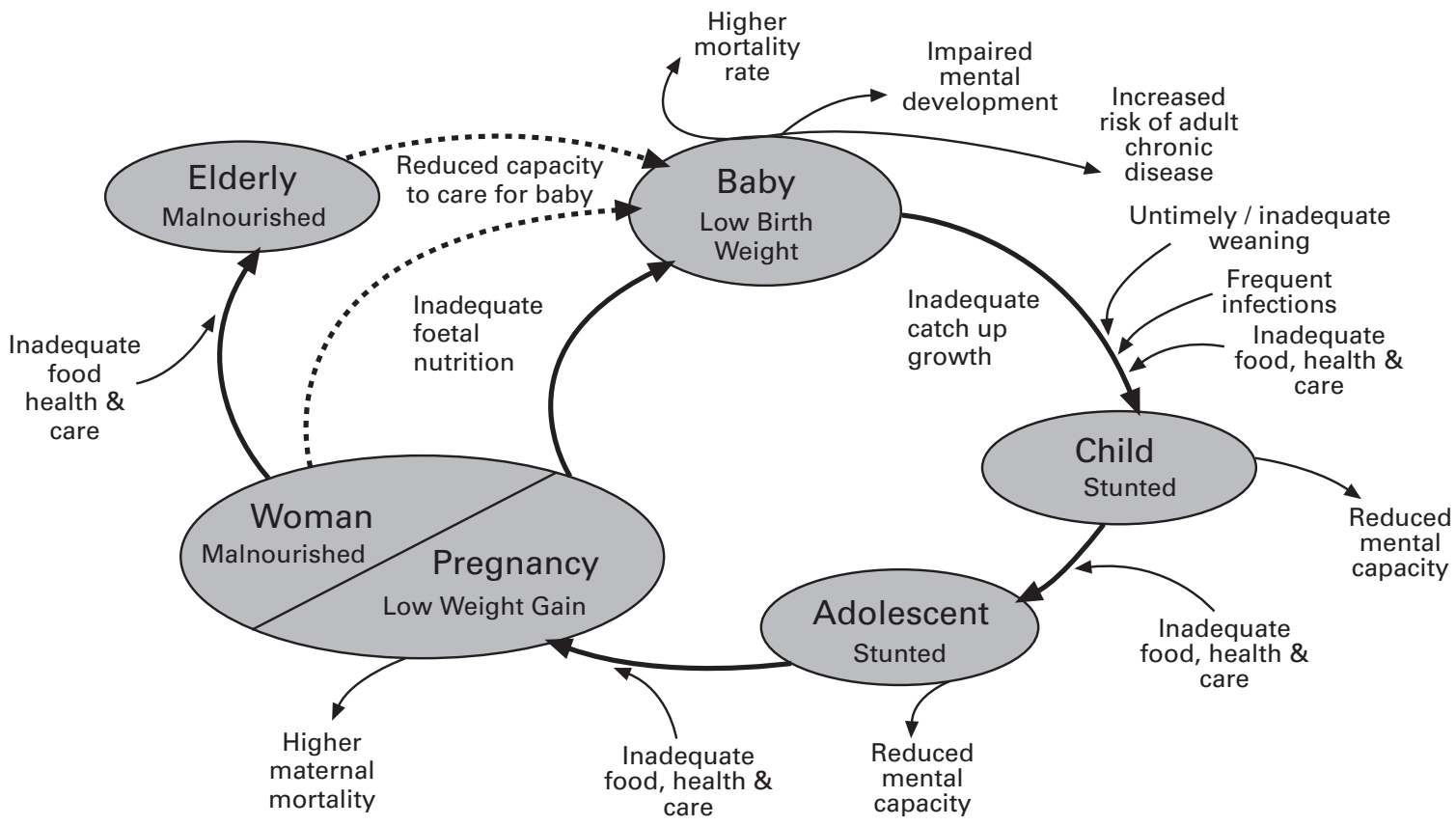

Fig. 2. Nutrition throughout the life cycle, demonstrating the intergenerational cycle of growth failure: young girls who grow poorly become stunted women and are more likely to give birth to low-birth-weight infants, who are likely to be stunted in adulthood. Adolescent pregnancy heightens the risk of low birth-weight and the difficulty of breaking this cycle. Support for good nutrition is needed in infancy, childhood, adolescence and adulthood, especially for girls and women. Reproduced from the Fourth Report on the World Nutrition Situation, ACC/SCN(2000).

\section{Cycle of entrapment: low birth weight/intrauterine growth retardation and stunting}

A second major constellation of negative impacts of hookworm in pregnancy is induced primarily by deficiencies of iron, total energy, protein, and possibly folate and zinc. These deficiencies are aggravated by the inhibition of appetite that occurs both in iron-deficiency anaemia and separately, in hookworm infection (Cline et al. 1984). The results are low pregnancy weight gain and intrauterine growth retardation (IUGR), followed by low birth weight, with its associated greater risks of infection and higher perinatal mortality rates. Stunting may follow, first in childhood and then in adulthood; in female children, this stunting will again lead to shorter mothers, low pregnancy weight gains, greater chances of IUGR and low birth weight (see Fig. 2). Such entrapment may explain why many individuals, and even large populations living in poverty with limited food supplies, with inadequate health care, and with high burdens of infectious and parasitic diseases, have relatively short stature, both as children (Fig. 3) and as adults.

The competitive physical, physiological and psychological edge denied to such individuals, especially in physically stressful situations, acute or chronic, decreases the probability of a person's or family's healthy survival. Particularly vulnerable are many of the rural women in Asia, sub-Saharan Africa, Latin America and elsewhere, who cope with the increased nutrient needs of either pregnancy or lactation for most of $\sim 20$ years of their lives, while on marginal diets too low in iron, and while nearly always responsible for growing all of the family's food crops, for minding the children, and for cooking, washing, and water-fetching.

New findings from Ghana and Tanzania also show that stunting may interfere importantly with primary school education by leading to late enrolment and possibly a higher probability of dropping out before completing primary school (Partnership for Child Development, 1999). Stunting was strongly associated with late enrolment in the schools studied in both countries (even though weight-for-age, weight-for-height $Z$-scores, and haemoglobin levels were not). Furthermore, stunting was independent of socioeconomic status (SES) in Tanzania, where SES was measured. The relationship between stature and age-appropriate grade was less marked in higher grades, a failing consistent with a higher drop-out rate for stunted children. Late enrolment with stunting occurred for both sexes, affecting not only how soon the children commenced formal education but also how long they were likely to study. Stunted girls, moreover, suffer doubly because of the reproductive sequelae detailed above.

Recent longitudinal observations on 2000 Filipino children support these findings and, importantly, also noted that children stunted between birth and 2 years of age had significantly lower scores on cognitive tests taken at 8 and 11 years of age than did non-stunted children (Mendez \& Adair, 1999). The shortfall in cognitive scores in children stunted in the 


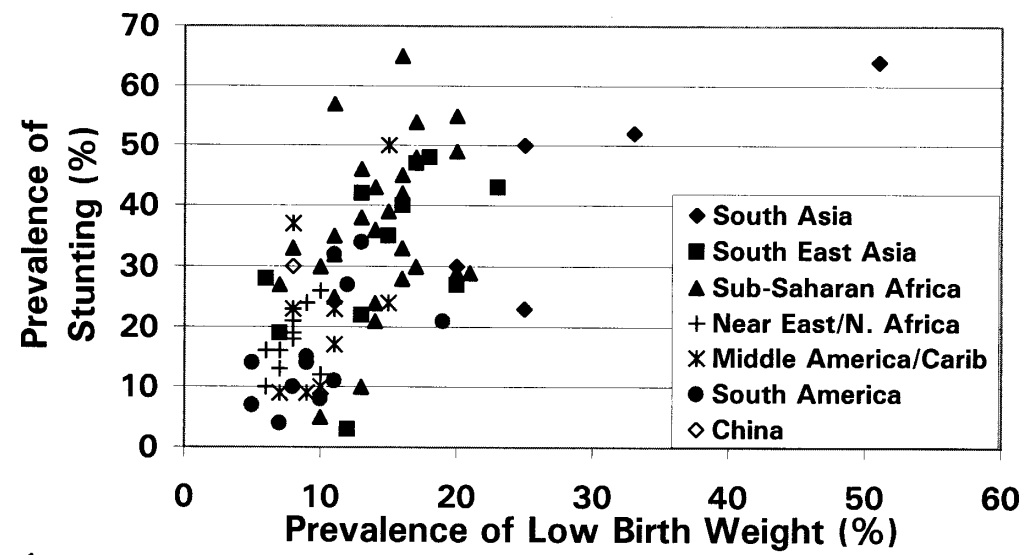

Fig. 3. Prevalence of low-birth-weight (LBW) and stunting; developing regions. Source: ACC/SCN (1997) [Notes: (a) Total low-birth-weight figures combine term and pre-term births. In most developing countries, most low-birthweight infants are full term, but have intrauterine growth retardation (IUGR). IUGR is a major clinical and public health problem in developing countries. It is defined as a deficit in weight of the foetus relative to that expected for gestational age. IUGR is an important cause of stunting, because small foetal size leads to LBW, which in turn is highly related to postnatal size (ACC/SCN, 1997). (b) IUGR contributes to closing the intergenerational cycle of poverty, disease and malnutrition (de Onis et al. 1997). (c) There is now convincing evidence (as reviewed by Scrimshaw, 1997) that foetal malnutrition lays the foundation for adult chronic disease. This has enormous consequences for policy-setting in countries where LBW is a public health problem (ACC/SCN, 1997)].

Table 8. Possible times in the lives of women to intervene with control of hookworm and potential objectives/benefits

\begin{tabular}{ll}
\hline \hline Time in life & Potential objectives/benefits \\
\hline Adolescence & Improve pre-pregnancy weight-for-height \\
& Improve pre-pregnancy iron status \\
Pregnancy and lactation & Related to mother \\
& Increase maternal iron stores \\
& Reduce maternal death in childbirth \\
& Reduce hospitalization rates for severe anaemia \\
and haemorrhage & Reduce caloric stress in pregnancy and lactation \\
& Related to infant \\
& Improve foetal growth; reduce low birth weight \\
& Improve iron stores of infants \\
& Prevent vertical transmission of Ancylostoma \\
Decrease perinatal mortality & Improve early childhood development \\
Throughout adult life & Improve economic productivity of women \\
& Improve wellbeing and quality of life \\
& Improve weight for height of all women \\
& Improve iron status in all women \\
\hline \hline
\end{tabular}

By R. Stoltzfus for WHO (1994).

first 2 years was strongly co-related with their reduced length of schooling that resulted from substantially delayed enrolment, higher absenteeism, and repetition of school years. Importantly, Guyatt (2000) discusses these issues in her comprehensive review of how intestinal nematodes per se may affect not only productivity in adulthood but also the ability to use educational opportunities. Among the major physical and mental developmental insults that occur in intestinal helminthiasis and that can interfere with productivity and wage earning ca- pacity of adults are anaemia, wasting, stunting, cognitive impairment and lowered educational achievement. There is strong indirect evidence that adult productivity decreases as a result of both early ill-health in childhood and recurrent infection and associated morbidity.

Hookworm infection is of major public health importance in undernourished pregnant girls and women because it adds major stresses on an organism already overtaxed. It causes gastrointestinal blood loss and inhibition of appetite (Cline et al. 1984) 
Table 9. Possible delivery systems for control of hookworm in women

\begin{tabular}{ll}
\hline \hline Time & Delivery systems \\
\hline Adolescence & $\begin{array}{l}\text { Secondary schools (Sri Lanka) } \\
\text { Women's groups (Indonesia) } \\
\text { Ritual initiation groups (Malawi) }\end{array}$ \\
Pregnancy and lactation & Antenatal care (Sri Lanka) \\
& Delivery services, TBA kits (Nepal, Bangladesh) \\
Throughout adult life & Community health worker systems (India) \\
& Traditional healers (Kenya) \\
& Women's groups or cooperatives (Indonesia, \\
& Bangladesh) \\
& Special women's days (Bangladesh, Nepal) \\
& Linkage to existing vertical campaigns,such as \\
& iodine, vitamin A, family planning (Indonesia, \\
& Nepal) \\
& Workplaces, such as cigarette or garment \\
& factories, plantations (Indonesia, Sri Lanka) \\
\hline \hline
\end{tabular}

By R. Stoltzfus for WHO (1994).

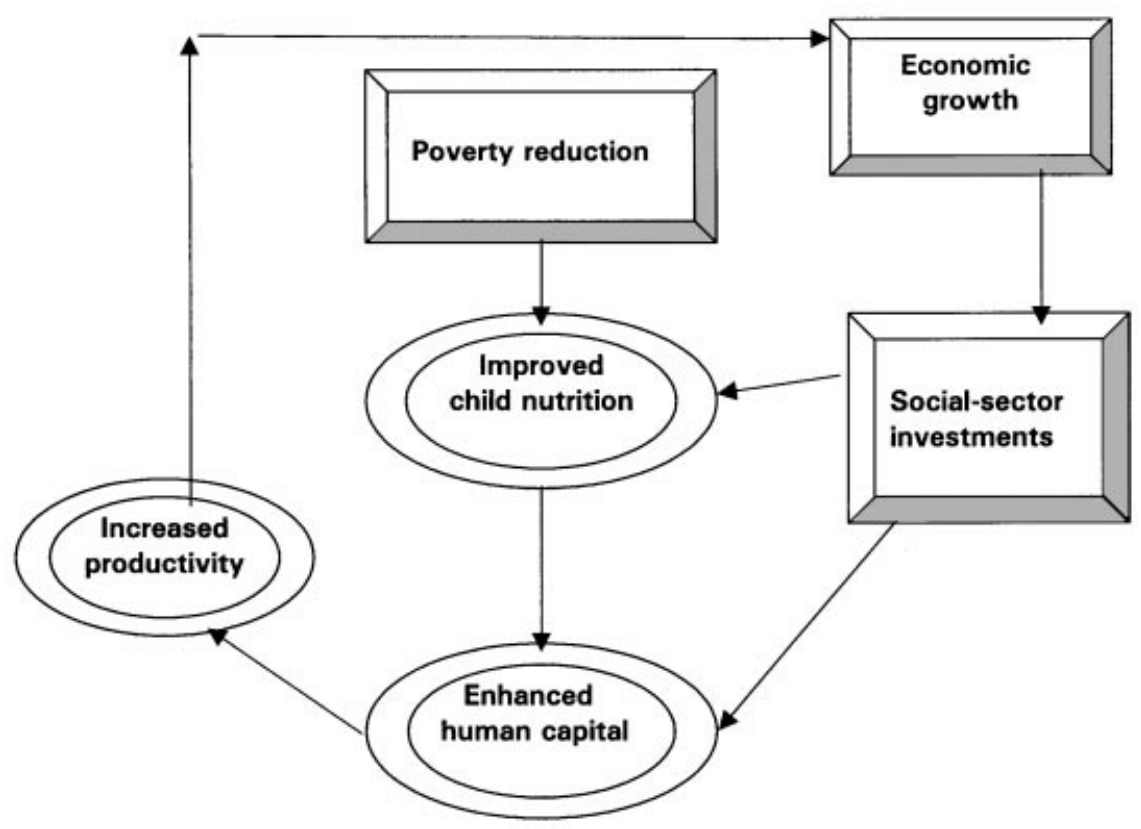

Fig. 4. From good nutrition to greater productivity and beyond: good nutrition is most likely to result where there is economic growth, especially equitable growth, where social services become affordable and accessible; and when adequate investment is made in human resources including empowerment of women. Good nutrition, in turn, contributes to greater productivity and thus to economic growth. Parasite control for hookworm, ascariasis and trichuriasis is part of better nutrition. Adapted from UNICEF (1997); Original source: Gillespie, Mason \& Martorell (1996).

which further aggravates the iron and energy deficiencies, protein and zinc deficiency, and the anaemia of pregnancy. Based on 1990 figures, an estimated 44.3 million of the developing world's $124 \cdot 3$ million pregnant women harboured hookworm infection (WHO, 1994). One can predict that at least $50 \%$ of pregnant women and more than $40 \%$ of preschool-age children in developing countries will be clinically anaemic (de Benoist, 1999). Data from child growth studies (Stephenson, 1993; Stephenson et al. $1993 a, b)$ and one study on weight gain in treated hookworm-infected pregnant women in Sierra Leone (Torless, 1999) suggest that even relatively light hookworm infections may decrease growth and therefore weight gain in pregnancy.

Hookworm anaemias are definitely a significant cause of the IUGR, low birth weight, and stunting that have major negative consequences for children, but these effects still have not been measured adequately and are not included in the current 
estimates of the global disease burden attributable to helminthiases. Considering that in India alone in 1990, there were about 25.9 million pregnancies and 10.9 millions of those likely hookworm-infected (WHO, 1994), one can see that the burdens tend to be truly staggering when quantified.

\section{Solutions for women and society}

The times when it is most useful to provide women with treatment/prevention for hookworm and the specific objectives/benefits of so doing, have been compiled by Stoltzfus for WHO (1994; Table 8). Table 9 identifies possible delivery systems one can use to achieve this control of helminths, along with examples of countries employing those systems. The intergenerational cycle of growth failure described in Fig. 2 illustrates (in Fig. 4) the wisdom of focusing on decreasing malnutrition and disease in vulnerable groups (particularly children and women of childbearing age) as a principal path to enhancing 'human capital' that can then lead to increases in productivity, economic growth, and poverty reduction - all of which will further improve child nutrition.

In areas with widespread hookworm anaemia in pregnancy and childhood, a principal tool to achieve the 'Improved Child Nutrition' seen at the center of Fig. 4 would be to decrease the parasitism that aggravates malnutrition. In such areas, the most important intervention to decrease stunting in childhood and increase productivity in a community may be to prevent/control hookworm in teenage girls and women, since infants born with weight in the normal range are so much less prone to morbidity and mortality, and more likely to be strong healthy adults. The earlier in a child's life that a nutritional insult occurs, the more episodes of morbidity it can cause or aggravate over time, especially since undernutrition at any age can compromise the host defense systems. Thus, preventing low birth weight, which means intervening directly with adolescent girls and mothers, should be an efficient and costeffective way to prevent the later childhood and adult stunting with its devastating consequences.

\section{ACKNOWLEDGEMENTS}

Grateful thanks go to Celia Holland, Helen Guyatt, Jaap Boes, Andrew Hall, Simon Brooker, D. W. T. Crompton, Renu Manjrekar; Judy Pojda and Sonya Rabeneck at $\mathrm{ACC} / \mathrm{SCN}$; colleagues in WHO, at Cornell University, in Denmark, and in SmithKline Beecham Ltd in Brentford, UK for their conversations, reprints, criticisms and moral support during preparation of the ms. We also thank Barb Seely and Charles Hunt for expert computer and general assistance. The senior author most gratefully acknowledges the WHO GPELF for providing both the consultant assignment to produce the $\mathrm{ms}$. and for financial support; The Danish Centre for Experimental Parasitology, Royal Veterinary \& Agricultural University, Frederiksberg, Denmark for institutional and financial support; and the Division of Nutritional Sciences, Cornell University for institutional support during its preparation.

\section{REFERENCES}

ACC/sCN (1992). Second Report on the World Nutrition Situation: Vol. I : Global and Regional Results. Geneva, ACC/SCN.

ACC/SCN (1997). Third Report on the World Nutrition Situation. December 1997. Geneva, ACC/SCN. ACC/sCN (2000). Fourth Report on the World Nutrition Situation. March 2000. Geneva, ACC/SCN.

ADAMS, E. J., STEPHENSON, L. S., LATHAM, M. C. \& KinOTI, S. N. (1994). Physical activity and growth of Kenyan school children with hookworm, Trichuris trichiura and Ascaris lumbricoides infections are improved after treatment with albendazole. Fournal of Nutrition 124, 1199-1206.

BENTLEy, M. E., STALlingS, R. Y., FUKUMOTO, M. \& ELDER, J. A. (1991). Maternal feeding behavior and child acceptance of food during diarrhea, convalescence, and health in the Central Sierra of Peru. American Fournal of Public Health 81, 43-47.

BROOKER, S., PESHU, N., WARN, P. A., MOSOBO, M., GUYATT, H., MARSH, K. \& SNOW, R. W. (1999). The epidemiology of hookworm infection and its contribution to anaemia among pre-school children on the Kenya Coast. Transactions of the Royal Society of Tropical Medicine and Hygiene 93, 240-246.

BUNDY, D. A. P., Chan, M. S., MEDley, G. F., JAMISON, D. \& SAvioli, L. (2000). Intestinal Nematode Infections. In Health Priorities and Burden of Disease Analysis: Methods and Applications from Global, National and Sub-national Studies. Cambridge, USA, Harvard University Press for the WHO and World Bank (in press).

Carvalho filho, E. (1978). Strongyloidiasis. Clinics in Gastroenterology 7, 179-200.

CHAN, M.-S. (1997). The global burden of intestinal nematode infections - Fifty years on. Parasitology Today 13, 438-443.

CHAN, M.-S., MEDLEY, G. M., JAMison, D. \& BUNDY, D. A. P. (1994). The evaluation of potential global morbidity attributable to intestinal nematode infections.

Parasitology 109, 373-387.

Cline, B. L., LitTle, M. D., BARTHOLOMEW, R. K. \& HALSEY, N. A. (1984). Larvicidal activity of albendazole against Necator americanus larvae in human volunteers. American Fournal of Tropical Medicine and Hygiene 33, 387-394.

COOPER, E. (1991). Intestinal parasitoses and the modern description of diseases of poverty. Transactions of the Royal Society of Tropical Medicine and Hygiene 85, 168-170.

COOPER, E. S., BUNDY, D. A. P., MacDONALD, T. T. \& GOLDEN, M. H. N. (1990). Growth suppression in the Trichuris dysentery syndrome. European Fournal of Clinical Nutrition 44, 285-291.

CROMPTON, D. W. T. (1984). Influence of parasitic infection on food intake. Federation Proceedings 43, 239-245.

CROMPTON, D. W. T. (1999). How much human helminthiasis is there in the world? Fournal of Parasitology 85, 397-403. 
DE BENOIST, B. (1999). Anaemia and iron deficiency anaemia: extent of the public health problem. INACG Symposium, 12 Mar 1999, Durban, South Africa. Dept of Nutrition for Health and Development, World Health Organization. DE ONIS, M., BLOSSNER, M. \& VILlaR, J. (1997). Levels and patterns of intrauterine growth retardation in developing countries. European Fournal of Clinical Nutrition 52 (Suppl.) S1, S5-15.

DE SILVA, N., CHAN, M. S. \& BUNDY, D. A. P. (1997b). Morbidity and mortality due to ascariasis: reestimation and sensitivity analysis of global numbers at risk. Tropical Medicine and International Health 2, 519-528.

DE SILVA, N. R., GUYATT, H. L. \& BUNDY, D. A. P. (1997a). Morbidity and mortality due to Ascaris-induced intestinal obstruction. Transactions of the Royal Society of Tropical Medicine and Hygiene 91, 31-36.

EVANs, A., Markus, M. B. \& STEYN, E. (1990). A survey of the intestinal nematodes of bushmen in Namibia. American Fournal of Tropical Medicine and Hygiene 42, 243-247.

EVANS, A. \& STEPhenson, L. S. (1995). Not by drugs alone: the fight against parasitic helminths. World Health Forum 16, 258-261.

GEORgI, J. R. (1982). Strongyloidiasis. In Handbook Series in Zoonoses (ed. Steele, J. H.) Section C: Parasitic Zoonoses vol II (ed. Schultz, M. G.), pp. 257-267. Boca Raton, Fla, CRC Press.

Gillespie, s., Mason, J. \& MARTORELl, R. (1996). How Nutrition Improves. Geneva, ACC/SCN.

GUERRANT, D. I., MOORE, S. R., LIMA, A. A. M., PATRICK, P. D., SChORLING, J. B. \& GUERRANT, R. L. (1999). Association of early childhood diarrhea and cryptosporidiosis with impaired physical fitness and cognitive function 4-7 years later in a poor urban community in Northeast Brazil. American Fournal of Tropical Medicine and Hygiene 61, 707-713.

GUYaTt, H. (2000). Do intestinal nematodes affect productivity in adulthood? Parasitology Today 16, 153-158.

HADJU, V., STEPHENSON, L. S., ABADI, K., MOHAMMED, H. O., BOWMAN, D. D. \& PARKER, R. S. (1996).

Improvements in appetite and growth in helminthinfected schoolboys three and seven weeks after a single dose of pyrantel pamoate. Parasitology 113, 497-504.

HADJU, V., STEPHENSON, L. S., MOHAMMED, H. O., BOWMAN, D. D. \& PARKER, R. S. (1998). Improvements of growth, appetite, and physical activity in helminthinfected schoolboys six months after a single dose of albendazole. Asia Pacific Fournal of Clinical Nutrition 7, 170-176.

hall, A., CONWAy, D. J., ANWAR, K. S. \& RAHMan, M. L. (1994). Strongyloides stercoralis in an urban slum community in Bangladesh: factors independently associated with infection. Transactions of the Royal Society of Tropical Medicine and Hygiene 88, 527-530.

HUMPhries, D. L., STEPHENSON, L. S., PEARCE, E. J., THE, P. H., DAN, H. T. \& KHANH, L. T. (1997). The use of human faeces for fertilizer is associated with increased intensity of hookworm infection in Vietnamese women. Transactions of the Royal Society of Tropical Medicine and Hygiene 91, 518-520.
LATHAM, M. C., STEPHENSON, L. S., KURZ, K. M. \& KINOTI, S. N. (1990). Metrifonate or praziquantel treatment improves physical fitness and appetite of Kenyan schoolboys with Schistosoma haematobium and hookworm infections. American Fournal of Tropical Medicine and Hygiene 43, 170-179.

LAWLESS, J. W., LATHAM, M. C., STEPHENSON, L. S., KinOTI, S. N. \& PERTET, A. (1994). Iron supplementation improves appetite and growth in anemic Kenyan primary school children. Fournal of Nutrition 124, 645-654.

MANJREKAR, R. R. (1999). Evaluation of the integrated management of childhood illness guidelines for treatment of intestinal helminth infections in sick children, 2-4 years, western Kenya. Master's of Public Health Thesis, Rollins School of Public Health. Emory University, 1999.

MANSFIELD, L. S. \& URBAN, J. F. (1996). The pathogenesis of necrotic proliferative colitis in swine is linked to whipworm induced suppression of mucosal immunity to resident bacteria. Veterinary Immunology and Immunopathology 50, 1-17.

MENDEZ, M. A. \& ADAIR, L. S. (1999). Severity and timing of stunting in the first two years of life affect performance on cognitive tests in late childhood. Fournal of Nutrition 129, 1555-1562.

Michael, E., BUNDY, D. A. P., Hall, A., SAVIOLI, L. \& MONTRESOR, A. (1997). This wormy world: Fifty years on - The challenge of controlling common helminthiases of humans today. Parasitology Today 13, poster.

MILDER, J. E., WALZER, P. D., KILGORE, G., RUTHERFORD, I. \& KLEIN, M. (1981). Clinical features of Strongyloides stercoralis infection in an endemic area of the United States. Gastroenterology 80, 1481-1488.

MOLLA, A. M., MOLLA, A. M., SARKER, S. A. \& RAHAMAN, M. M. (1983). Food intake during and after recovery from diarrhoea in children. In Diarrhoea and Malnutrition: Interactions, Mechanisms, and Interventions (ed. Chen, L. D. \& Scrimshaw, N. S.), pp. 113-123. New York, Plenum Press.

MOORE, S. R., LIMA, A. A. M., SCHORLING, J. B., CONAWAY, M. \& GUERRANT, R. L. (1999). Early childhood diarrhea $\&$ helminthiases associated with long-term stunting. American Fournal of Tropical Medicine and Hygiene 61, 385 .

MURRAY, C. J. L. \& LOPEZ, A. D. eds (1994). Global Comparative Assessments in the Health Sector Disease Burden, Expenditures and Intervention Packages. Geneva, World Health Organization.

MURRAY, C. J. L. \& LOPEZ, A. D. eds (1996). Global Burden of Parasitic Worm Infections. In Global Burden of Disease and Injury Series, vol II. Global Health Statistics. Cambridge, USA, Harvard University Press. NONAKA, D., TAKAKI, K., TANAKA, M., UMENo, M., TAKEDA, T., Yoshida, M., HaRAGUChI, Y., OKADA, K. \& SAWAE, Y. (1998). Paralytic ileus due to strongyloidiasis: case report and review of the literature. American Fournal of Tropical Medicine and Hygiene 59, 535-538.

PARTNERSHIP FOR CHILD DEVELOPMENT (1999). Short stature and the age of enrolment in Primary School: studies in two African countries. Social Science and Medicine 48, 675-682.

ROSENBERG, I. H. \& BOWMAN, B. B. (1984). Impact of 
intestinal parasites on digestive function in humans. Federation Proceedings 43, 246-250.

SCRIMSHAW, N. (1997). The relation between fetal malnutrition and chronic disease in later life. British Medical Fournal 315, 825-826.

SCRimshaw, N. S. \& SANGiovanni, J. P. (1997). Synergism of nutrition, infection, and immunity: an overview. American Fournal of Clinical Nutrition 66, 464S-477S. solomons, N. s. (1993). Pathways to the impairment of human nutritional status by gastrointestinal pathogens. In Human Nutrition and Parasitic Infection (ed. Crompton, D. W. T.). Parasitology 107, S19-S35. STEER, P. J. (2000). Maternal hemoglobin concentration and birth weight. American Fournal of Clinical Nutrition 71, 1285S-1287S.

STEPHenson, L. S. (1993). The impact of schistosomiasis on human nutrition. In Human Nutrition and Parasitic Infection. Parasitology 107, S107-S123.

STEPHENSON, L. S. \& HOLLAND, C. v. (1987). The Impact of Helminth Infections on Human Nutrition. London, Taylor \& Frances, Ltd.

STEPHENSON, L. S., LATHAM, M. C., ADAMS, E. J., KinOti, S. K. \& PERTET, A. (1993a). Weight gain of Kenyan school children infected with hookworm, Trichuris trichiura and Ascaris lumbricoides is improved following once- or twice-yearly treatment with albendazole. Fournal of Nutrition 123, 656-665. STEPHENSON, L. S., LATHAM, M. C., ADAMS, E. J., KinOti, S. N. \& PERTET, A. (1993b). Physical fitness, growth, and appetite of Kenyan schoolboys with hookworm, Trichuris trichiura and Ascaris lumbricoides infections are improved four months after a single dose of albendazole. Fournal of Nutrition 123, 1036-1046.

STEPHENSON, L. S., LATHAM, M. C., KURZ, K. M., KINOTI, s. N. \& BRigham, H. (1989). Treatment with a single dose of albendazole improves growth of Kenyan school children with hookworm, Trichuris trichiura, and Ascaris lumbricoides infections. American Fournal of Tropical Medicine and Hygiene 41, 78-87.

TORLESs, H. (1999). Parasitic infections and anaemia during pregnancy in Sierra Leone. Ph.D. Dissertation: University of Glasgow.

UNICEF (1997). The State of the World's Children 1998. Oxford, Oxford University Press and United Nations Children's Fund.

WARREN, K. S., BUNDY, D. A. P., ANDERSON, R. M., DAVIS, A. R., HENDERSON, D. A., JAMISON, D. T., PRESCOTT, N. \& SENFT, A. (1993). Helminth Infections. In Disease Control Priorities in Developing Countries (ed. Jamison, D. T., Moseley, W. H., Measham, A. R. \& Bobadilla, J. L.), pp. 131-160. Oxford University Press, Oxford.

WORLD BANK (1993). World Development Report: Investing in Health. Oxford, Oxford University Press. WORLD HEALTH ORGANization (1994). Report of the WHO Informal Consultation on Hookworm Infection and Anaemia in Girls and Women, Geneva, 5-7 December. WHO/CDS/IPI/95.1, Geneva, WHO. 